\title{
Becoming American: Constructing Mexican Immigrants in Local Newspapers
}

\author{
Zheng Zhu \\ Correspondence: Zheng Zhu, Department of Humanities, NYC College of Technology, 300 Jay St, Brooklyn, NY 11201, \\ USA
}

Received: September 1, 2015 Accepted: November 10, 2015 Online Published: December 1, 2015

doi:10.11114/smc.v3i2.885

URL: http://dx.doi.org/10.11114/smc.v3i2.885

\begin{abstract}
Media representation of Latino immigrants has been extensively studied by scholars across diverse academic disciplines. Particular to the U.S. context, preceding scholarships pertaining to the ways in which Latinos were represented centered on the media representation of Latino immigrants either as the exotic racial other or undesirable foreigners. In light of the important role that the Mexican immigrants played in understanding the current national debate on illegal immigration and the overall historical experiences of immigrants in Washington State (WA), this study critically investigated how news articles published in WA represented Mexican immigrants. As a crucial point of departure from prior studies' focus on media representation in national context and lack of an in-depth inquiry into how the contextual elements operate to affect media coverage, the present study revealed that the local news media constructed Mexican immigrants as the racial other through a dialectical articulation and the assimilationist rhetoric. Key implications for future research were offered at the end for continuing exploration of media representation of immigrants.
\end{abstract}

Keywords: Mexican, immigrants, media, context, representation

\section{Introduction}

The stereotypical representations of Mexican immigrants received numerous critical attentions from scholars in the field of intercultural and international communication studies (Lopez, 1991; Ono \& Sloop, 2002; Sanchez, 2014; Vargas, 2009). From a broader level of consideration, majority of these critical projects attempted to unearth how Mexican immigrants, defined as a particular racial category, were viewed and positioned by American society. Although the dominant U.S. discourse tends to homogenize Mexican immigrants into the larger pan-ethnic group as Latinos, an emerging group of researchers started examining how Mexican immigrants within certain historical contexts and geographical locations are constructed by the news media. Nevertheless, these pioneering studies either set eyes on media representation in national context or presumably investigated the representation on a national scale. They ignored the subtle contextual variations that could shape the political and rhetorical functions of news discourse. Hence, to expand the current line of critical investigation on media representation, and with a new attention to local news media, this study unraveled how Mexican immigrants were constructed by local newspapers.

\subsection{Context: History of Mexican Immigrants in Washington State}

Focusing on the migratory movements and memory of early Mexican immigrants in the State of Washington, Ruiz and Chavez's (2008) historical account detailed how Mexican immigrants first came to the United States as farmworkers. Starting with colonial expansion and domination led by Spanish explorers in 16 century, Mexico claimed its national independence from Spanish rulers after hundreds' years of struggle and combats (Ruiz \& Chavez, 2008, p. 153). What accompanied Mexican independence was the arrival of the first group of Mexican Immigrants in Washington State (WA) during the early $19^{\text {th }}$ century (Ruiz \& Chavez, 2008, p. 153-154). Due to the fact that WA's primary economic incomes relied on farming, the majority of Mexican immigrants were employed as non-contract farmworkers (or referred to as Braceros) who had to endure tough living and working conditions in rural areas such as Yakima Valley and Walla Walla until an official contract labor program was established in 1917 (Ruiz \& Chavez, 2008, p. 154-156; Scruggs, 1960, p. 320).

The economic blossom of Washington State was largely attributed to Mexican immigrants' succumbing to the hegemonic practice of global capitalism (Ruiz \& Chavez, 2008). Marked by low cost and excessive labor work, Mexican immigrants' contribution to the farming industry of Washington State is significant (Ruiz \& Chavez, 2008). 
Meanwhile, the rise of Mexican population, as a result of the increasing need for labor force on the farming site, offered future immigrants more opportunities to move up the socio-economic ladder (Ruiz \& Chavez, 2008, p. 160-163). However, as the movement of immigration progressed over several decades, the assimilationist discourse and internal class stratification emerged casting negative impact on the relations among Mexican immigrants (Ruiz \& Chavez, 2008, p. 166). Using elite Hispanic politicians as an example, Ruiz and Chavez revealed elite immigrants' successful integration into mainstream society as they gained powers and recognition in politics, however losing sight of structural oppression against the ethnic minorities (p. 167).

Ruiz and Chavez's critique of successful Latino politicians' self-distancing from the working-class aspects of their heritage alluded to the lack of understanding that the younger Latino immigrants held towards the older generation's struggle with racism, classism and sexism. Moreover, this lack of understanding could be read as an inter-generational gap due to each generation's differing experiences with racial hierarchy and patriarchal system. Thus, to eliminate sociopolitical oppressions that have long been inflicted upon Mexican immigrants, it is important to both identify and close the gap that blocks the productive dialogues within the immigrant communities (Ruiz \& Chaves, 2008).

Given the important role that the Mexican immigrants play in affecting the dominant media representation of Latino immigrants and the long socio-political debate that tends to subject Mexican immigrants to the racist criticism, Ruiz and Chavez's study could be used as valuable resources for an inquiry into how Mexican immigrants are constructed through the dominant cultural lens. Ensuing discussion will follow this line of thinking by surveying literature that examined dominant representation of immigrants, with a specific attention to how the images of Mexican immigrants were constructed in prevailing U.S. media texts. Further, larger theoretical ideas will be highlighted so as to unveil the broader issues related to popular media representation, discourse of racism, and the processes of globalization.

\subsection{U.S. Media Representation of Latino/Mexican Immigrants}

In their book Shifting Borders: Rhetoric, Immigration, and California's Proposition 187, Ono and Sloop (2002) focused their critical lens on Los Angeles Times' rhetorical construction of illegal immigrants, and how the (California) local Nativism was both entrenched and affirmed through varying forms of rhetorical strategies. As proclaimed by Ono and Sloop, preceding scholarship did not pay sufficient attention to the critical influence that a particular state-oriented nativism placed on the overarching structural framework of national nativism (p.43). Following this claim, Ono and Sloop investigated how news media legitimized and further reified the dominant cultural and political discourse of California nativism.

Using the nationally-known and circulated Los Angeles Times as texts for examination, several important thematic issues emerged. These themes portrayed illegal immigrants as threats to the cultural integrity, political stability, and economic prosperity of the United States (Ono \& Sloop, 2002). The authors further unpacked the rhetoric of American nationalism, xenophobic racism, and neo-colonialist sentiments. These rhetorical patterns criticized illegal immigration and supported proposition 187. The newspapers emphasized the important role that the law played in both regulating the movement of illegal immigration and protecting the national border of the United States (Ono \& Sloop, 2002, p. 45-47). The newspapers constructed illegal immigrants, mainly undocumented Mexican immigrant workers, as criminals violating U.S. immigration law. However, no news reports explained how prior colonialist domination and existing political oppression forced these immigrants to participate in the capitalist system of production and exploitation (Ono \& Sloop, 2002).

Ono and Sloop pointed out that both the proponents and opponents of Proposition 187 supported the dominant rhetoric, which excludes illegal immigrants from the imagination of U.S. cultural landscape. For example, the Los Angeles Times' highlighting of Mexican national flag as a "common scenery" in California and the newspaper's accusation of the immigrants as "disease spreaders" echoed the mainstream media's representation of illegal immigrants as the racialized, nationalistic, and contaminated enemies (Ono \& Sloop, 2002, p. 52-53). Further, the Los Angeles Times' construction of illegal immigrants as economically destructive, whereas at some points as cheap labors beneficial to the state economy created and fortified the border, which kept the illegal immigrants out as the inferior others (Ono \& Sloop, 2002).

More than just studying how media represent illegal immigrants, Stewart, Pitts and Osborne's (2011) study examined how the negative representation of illegal immigrants affected the intergroup communication between the local white residents and Hispanic community. Stereotyped as dangerous aliens, illegal immigrants were constructed by the newspaper articles as a metonym for Latino immigrants. This unfavorable representation intensified the antagonistic sentiments that the white residents held against local Latino immigrants (Stewart, Pitts \& Osborne, 2011, p. 18). Meanwhile, fear and anxiety preoccupied Latino immigrants who watched media's stigmatizing representation of undocumented immigrants (Stewart, Pitts \& Osborne, 2011, p. 19). Stewart, Pitts and Osbone's research revealed the barriers created by the local news media. Such barriers impeded the productive cross-cultural communication and 
interracial relations.

Moving beyond the critical study of a particular group of people or a specific type of media text, an emerging group of scholars studied the broader structure of media representation, with a specific focus on the interwoven relationship among racism, popular media, and globalization. For example, Watson and Riffe (2013), Miller (1994), van Dijk (1988), Zepeda-Millan (2014), Downing and Husband (1995) examined the crucial aspects of media representation of immigrants focusing on ways through which the immigrants were positioned in relation to the host society. They argued that the dominant media placed immigrants on the nation's margin by highlighting their illegal entry, unlawful stay, and negative impact on the host society's stability and prosperity (Downing \& Husband, 1995; Miller, 1994; van Dijk, 1988; Watson \& Riffe, 2013; Zepeda-Millan, 2014). The media's xenophobic discourse was usually normalized, or even glorified through nationalist representations (Downing \& Husband, 1995; Miller, 1994; van Dijk, 1988; Watson \& Riffe, 2013; Zepeda-Millan, 2014). Thus, a critical reading of media representation of immigrants entailed scholars' in-depth analysis of the ways media use words and pictures to represent immigrants, and a further inquiry into the complex socio-political context in which immigrants inhabited (Downing and Husband, 1995; van Dijk, 1988, p. 182).

Moreover, critical media scholars should be sensitive to what is absent in the text. At this part, Don and Lee (2014), Schemer (2012), Van Dijk (1988), Ono and Sloop (2002) all highlighted immigrants' contribution to the local and national economy as cheap labors. They hinted at immigrants' impossibility of stealing job opportunities from local residents due to former's lack of relevant working experiences, low language proficiency, and unlawful status. This argument resonated with Lopez (1991), Dunaway et al (2011), Ruiz (2002), and Vargas' (2009) critical interrogation of the mainstream U.S. media's representation of Latino immigrants as social illness and contagious diseases. Both Ruiz and Vargas pointed at the contradictory representations of Mexican immigrants as a threat to the job market, and meanwhile being assigned to a lower socio-political class. As Ruiz and Vargas asserted, the critical analysis of media representation of immigrants needs to be attentive to these nuanced points, references, and implications of the dialectical tension that functions to legitimate the representation.

As a state that has been historically known as the land of farming in the United States, WA owes its rapid economic development to the persistent and tireless works that the Mexican immigrants provided throughout $19^{\text {th }}$ and $20^{\text {th }}$ century (Ruiz \& Chaves, 2008). Even today, Mexican immigrants are still considered a vital part of the farming industry in WA. Compared to the scant historical account of Mexican immigrants, research on how media outlets from WA represented Mexican immigrants has not even been found in any forms of published manuscripts. Hence, drawing on the theoretical framework of the media representation of Hispanic immigrants, following research question is identified: How are Mexican immigrants represented in Media texts published in Washington State?

\section{Method}

\subsection{Critical Discourse Analysis (CDA)}

CDA focuses on how power relationships are created and normalized in the discourse. CDA treats larger social context as a contested space where struggles for power domination never ends (Fairclough \& Wodak, 1997, p. 264). Thus, critical methodologist theorizes society as founded by an oppressive regime where power inequality is sustained and perpetuated (Fairclough \& Wodak, 1997, p. 263). The main functions of the CDA is to uncover how the dominant discourse positions the marginalized others in relation to the dominant groups and in what ways such positioning reflects the larger struggles between the center and periphery (Fairclough, 2009).

In his critical analysis of the journalistic discourse, Richardson (2007) asserted that the language of journalism "has some very specific textual characteristics, methods of text production and consumption, and is defined by a particular set of relationships between itself and other agencies of symbolic and material power" (p. 1). His further argument draws on Fairclough's (2009) theory of critical discourse analysis and Van Dijk's (1988) conceptual framework of critical media studies; compared to other media outlets, newspaper articles place more emphasis on the objective aspects of the issues that are being covered. They also enable a critical reading of the larger context where the text is produced (Richardson, 2007). In other words, the socio-cultural condition that legitimates the production of the news stories can be revealed through a critical examination of the discourse, which includes the lexical and syntactic genre, the angle of reporting, and the pictorial representation attached to the articles (Richardson, 2007). As Richardson pointed out, a news article does not just give you an intriguing story. It lends insight to the material condition and social system that legitimates the ways a story is articulated.

\subsection{Data Collection}

Informed by the theoretical tenets of CDA in newspapers, I purposefully selected newspapers across 6 cities and towns, where the presence of Mexican immigrants was significantly higher than other regions in WA. They are Seattle, Yakama Valley, Walla Walla, Spokane, Pasco, and Tacoma (Calvert, 2002; Ruiz \& Chavez, 2008). Following this step, I used 7 
key words to locate articles relevant to my analysis of issues pertaining to Mexican immigrants. These 7 words are Latino, Latina, Mexican, Immigrants, Hispanic, Immigration, and Border. In order to capture the most updated and comprehensive news coverage of Mexican immigrants, I choose the year 2000-2011 as the timeline for data collection. The beginning of the new millennium witnessed the emergence of massive U.S. media representations of Mexican immigrants, and this phenomenon is the result of the intensifying nationwide debates on illegal immigration (Ono \& Sloop, 2002, p. 12; Ruiz \& Chavez, 2008, p. 5).

Under this timeframe, I entered the key words in World News-Bank, an online software designed to search for news articles. More than 3000 newspapers were found. I omitted ones that neither focused on Mexican immigrants nor described Mexican immigrants beyond the level of superficial depictions. Finally, 300 articles were selected for coding the concurrent themes. Due to the limitation in research funding and the intervention of my other teaching and research obligations, it took me on and off 6 months to collect, select, and code data. These 300 articles were published by the following newspaper sources; Yakama Herald-Republic, Walla Walla Union-Bulletin, The News Tribune, Tacoma Daily Index, The Spokaneman-Review, Tri-City Herald, The Seattle Times, and West Seattle Herald, the analysis that proceeds will specify the emerging themes.

\section{Results}

\subsection{Love-Hate Binary}

When being asked about her attitudes towards Mexican immigrants, an interviewee named Lauren commented; "on the one hand, we are very, very dependent on Latino labor. On the other hand, there is an incredible amount of xenophobia that's on the rise. It is extremes. Nobody is in the middle" (2006, p. 6, The Seattle Times). Media representation of Mexican immigrants supported a polarized discourse pattern, which positions Mexican immigrants as being needed by the tertiary industry, but on the other hand, bringing down the economy due to their growing influence and power in food industry, rising population in the United States, and the increasing competition with American working class in the job market. In Spokaneman-Review and Yakama Herald-Republic, Mexican immigrants were described as "have been growing very fast over past decade, and they definitely contribute to the changing economic structure of Washington State" (Yakama Herald-Republic, 2008, p. 10; Spokaneman-Review, 2009, p. 8).

By indicating the rapid pace of population growth in Mexican immigrant community, Spokaneman-Review implicitly revealed public anxiety of not knowing what it was going to happen if this racial group kept expanding in the area. Through citing economic experts' pessimistic forecast on current economic situation, which led to the shrinking funds for educational resources and job opportunities, the articles published by Spokaneman-Review held negative tone pointing at the detrimental impact that the growing number of Mexican immigrants were casting on the economic recession. The implication of "changing economic structure" pointed towards the disastrous consequences of letting Mexican immigrants grow without proper regulation. Taking a different direction, Yakama Herald-Republic's description of Mexican immigrants as "growing fast" showed complex and dialectical understanding of Mexican immigrants as illegal in nature, yet valuable to the economy only during harvest farming season. But when economy went down, Mexican immigrants immediately became the target of public criticism due to the accusation that they added extra burden to the recession.

Yakama Herald-Republic and Tacoma Daily Index complimented Mexican immigrants for their years of contribution to the development of farming industry in WA. These two newspapers also argued that the Mexican immigrants could easily find jobs because they never asked for high pay or other types of benefits due to their illegal status (Tacoma Daily Index, 2006, p. 12; 2007, p. 9; 2011, p. 8; Yakama Herald-Republic, 2007, p. 9; 2009, p. 7; 2010, p. 11). However, during economic down time, Mexican immigrants were seen as posing unforeseeable threat to the economic recovery of both WA as a particular region and the United States as a nation (Walla Walla Union-Bulletin, 2009, p. 11-12; Yakama Herald-Republic, 2009, p. 8). In these newspaper articles, one of the major arguments critical of the Mexican immigrants' presence was they were illegal and evading taxes, but they still received social benefits from government (The Seattle Times, 2010, p. 7-10; 2011, p. 8-10; Tri-City Herald, 2008, p. 5-6; 2009, p. 7-10; 2010, p. 6-8; West Seattle Herald, 2009, p. 3-5). None of these articles talked about the inferior working condition and the below poverty-line payment that the Mexican immigrants had to endure when they were vehemently blamed for the illegal entry and tax evasion. From a broader level of examination, illegality is defined as the marker of Mexican immigrants' identity.

Framed as illegal and undocumented, the surveyed media texts homogenized both legal Mexican immigrants and illegal Mexican immigrants into one socio-racial category: illegal immigrants from Mexico. Without paying attention to the Mexican immigrants who came to the United States through legal channel, the image of Mexican immigrants was stigmatized as inferior trespassers in the first place through a discursive negation of their political status and cultural citizenship.

Moreover, Mexican immigrants were considered playing an important role in the farming and construction industry. The 
core reason was their low demand for payment and high tolerance for tough working and living conditions. Nevertheless, this critical aspect did not receive consistent and in-depth coverage examining the exploitative practice of farming industry in WA.

Therefore, the desire of employing Mexican immigrants should be largely attributed to the economic benefits they can contribute to the state's farming industry (Ruiz \& Chavez, 2008). This objectification of Mexican immigrants as cheap and disposable economic commodities matched the way the newspapers represented them as the uneducated, poor and filthy racial other who "have all these babies one right after another" (The News Tribune, 2008, p. 12). The representation of Mexican immigrants as seemingly loved by the host society due to their cheap price for employment, whereas hated because of the public fear and anxiety towards their excessive growth and low socio-economic condition reflects the racist discourse that perpetuates the ideological exclusion of the racial other.

\subsection{The American Dream}

Mainstream media representation tends to support the ideological construction of reality (Hall, 1997). Drawing on this foundational concept, the newspapers' reification of American dream can be detected through a critical reading of the news discourse, which affirms the logics of neoliberal ideology. Neoliberal discourse naturalizes the ideal of fair competition by attributing one's failure in reaching success to the individual's ineptitude (Aguirre \& Simmers, 2011). An important function of neoliberal discourse is to erase the oppressive system that glorifies the marginalized group's subordination to the ruling class, who controls the competition (Aguirre \& Simmers, 2011). For instance, The Seattle Times reported several successful life and career experiences of Mexican immigrants, who were described as coming to United States as illegal immigrants, but eventually gaining legal citizenship, social respect, and financial wealth through persistent diligence, dedication, and honesty at work (The Seattle Times, 2005, p. 8-9; 2007, p. 6-8; 2011, p. 6-9). According to West Seattle Herald and Tri-City Herald, not all Mexican immigrants were "struggling to make a living by earning minimum wages, some of them managed to become financially well-off, had families, and assimilated into American way of living" (Tri-City Herald, 2007, p. 5-6; 2008, p. 7-8; West Seattle Herald, 2008, p. 7-8).

From illegal immigrants to legal American citizens, these examples of successful Mexican immigrants demonstrated that American dream is reachable and accessible to anyone as long as you are willing to work hard and stay loyal to your goal. In particular, Spokaneman-Review published an article that narrated a Mexican immigrant's 20 years of living in the United States. As someone who arrived in U.S. illegally, Luis (the name used by the newspaper) worked different jobs in Seattle, Spokane, and Yakama (Spokaneman-Review, 2010, p. 5-7). In the end, he found a job at a restaurant located in downtown Spokane (Spokaneman-Review, 2010, p. 5-7). His American boss was highly impressed by his working performance and greatly touched by the "enduring commitment" and "exceptional work ethics" he exhibited over the past 7 years (Spokaneman-Review, 2010, p. 5-7). Just in last year, Luis gained legal citizenship under the help of his boss (Spokaneman-Review, 2010, p. 5-7). Now, Luis is having a stable job, with decent income and social status. He has two wonderful children who are going to college in Seattle next year (Spokaneman-Review, 2010, p. 5-7).

Using a similar narrative format, Walla Walla Union-Bulletin gave an inspirational story about a local Mexican immigrant fighting his way to earn the respect from his white American boss and become the leader of the local farming community. The anecdote offered by Walla Walla Union-Bulletin emphasized how this Mexican immigrant, named as Carlos, built a strong cross-racial friendship with his white American boss over the past decade. With a particular focus on how much Carlos has sacrificed to work long hours and help his boss, who in return, took great care of Carlos and his families, this article showed how an illegal immigrant who did not speak proper English and had no formal education could become successful only under one condition: work hard, and, do not ever say no or complain to your boss about working overtime (Walla Walla Union-Bulletin, 2009, p. 7-8).

The aforementioned summary of two narrative accounts embeds a very important message to their readers: if they can do it, you can do it too. Using just work hard no matter what mentality to highlight the only way that illegal immigrants can become successful was to abide authority, these two articles supported the hegemonic fantasy created by the rhetoric of American dream and echoed other articles that blamed Mexican immigrants failing to acquire success on their own incapability and lack of motivation. Meanwhile, the news reports also cited how the successful immigrants criticized the lazy immigrants as the latter learned things slowly and did not try their best to achieve success (Spokaneman-Review, 2006, p. 12; 2008, p. 10; 2010, p. 8; Tacoma Daily Index, 2011, p. 8-9). Thus the complex issues related to illegal immigration were reduced to personal choice and incompetence. Not only were the historical, political and economic factors that forced Mexican immigrants to leave their countries of origin erased from the larger picture, but domestic oppressions against the immigrants within WA were also rendered invisible through a series of highly dramatic and selective accounts of a few Mexican immigrants' successful life and working experiences. 


\subsection{Rhetoric of Legality}

One of the newspapers' main arguments was that illegal Mexican immigrants violated U.S. immigration law and policy. This issue was constantly brought up by interviewed American citizens who argued that the illegal immigrants needed to be sent home because what they did was unlawful. The U.S. immigration law was constructed as fair to everyone who wanted to acquire legitimate resident status. However, whose position was privileged in the immigration law and does the current law equally address everyone's need and situation were not mentioned.

Almost everyone who had been interviewed or cited by the newspapers, ranging from people walking on the street to anti-immigration activists, positioned themselves as equal to illegal immigrants when standing in front of law and constitution. Statements such as "Everyone must go through the same procedure" and "we all must follow the law" were strategically employed in the news texts to shield the power hierarchy supported by the discourse of law from being found (Spokaneman-Review, 2003, p. 8; The News Tribune, 2007, p. 6, 2008). For example, some interviewees argued that my ancestors came here legally, then why could not they do the same (The Seattle Times, 2011, p. 9; Tri-City Herald, 2005, p. 6; Yakama Herald-Republic, 2010, p. 7)? However, in the following section of The Seattle Times, the author wrote that "but these accounts are flawed, historians say. Until 1918, the United States did not require passport; the term 'illegal immigrants' had no meaning" (The Seattle Times, 2011, p. 9). At this part, the news discourse implied how law was created to privilege the dominant racial and cultural group. In the meantime, the invisible racial privilege was also disclosed opening up for critical investigation through interviewees' recounting of their ancestors' immigration experiences to question why Mexican immigrants cannot follow the same route?

In many news articles, the term illegal was de-historicized, or de-contextualized in the discussion of immigration. As Ono and Sloop proclaimed, the dominant rhetoric of immigration perpetuates the myth that the United States was forever a country founded on immigrants. This myth creates the perception that America is a haven for immigrants of all national origins and ethnic backgrounds (Ono \& Sloop, 2002, p. 42). The creation of such perception downplays the different immigration experiences between immigrants of distinct socio-racial identities.

Moreover, the public discourse of immigration also underwent transformations over the past $20^{\text {th }}$ century. The ways the immigrants were imagined by the general public have changed to a great extent. People tend to identify immigrants as poor and uneducated individuals coming to America through illegal channels (Brattston, 2014). They think immigrants as people who came from underdeveloped countries and are willing to do jobs that do not require strong educational background and language proficiency (Brattston, 2014). They do not see or call immigrants coming from wealthy countries such as those located in the Western Europe as immigrants (Brattston, 2014). Hence the larger discourse of immigrants carries the strong racist and imperialist sentiments, which serve to re-define the nation's other (Brattston, 2014). As pointed out by to Ono and Sloop, understanding the existing immigrants' cultural experiences and identities is always a complicated process. In this process, scholars need to be sensitive to the racist, nationalist, and imperialist discourse driving the domination construction of immigrant identity (Ono \& Sloop, 2002).

\subsection{Becoming American}

Rather than addressing thorny issues related to illegal immigrants, some articles took a different direction; they wrote stories celebrating some Mexican immigrants' successful integration into the host society. These articles argued that not all Hispanic immigrants struggled with poverty, had low education, and fear deportation. They paid attention to the fact that the next generation of Mexican immigrants succeeded in receiving good grades in school, earning respect from local communities, and speaking English with perfect American accent. For example, The Seattle Times, Tacoma Daily Index, and Tri-city Herald praised the Mexican immigrants' children's successful assimilation into the host society. The articles published by these three newspapers focused on how the hard work of these Mexican immigrants paid off because their children were doing great in school. Some of them were even getting jobs that their parents could only dream of.

However, as further unpacked by the authors of these news stories, a lot of second or third generation of Mexican immigrants could not speak Spanish or showed no interest in learning the language. This phenomenon was celebrated as these Immigrants' successful transition into the host society (The Seattle Times, 2011, p. 7). As indicated by The Seattle Times, the interviewed Mexican immigrants never told their children about the difficult journey their parents treaded through to achieve citizenship in the United States (p. 7). One of the major explanations offered by the interviewees was that they wanted their children to not think of themselves as different from the local American kids and completely assimilate into the dominant cultural group (The Seattle Times, 2011, p. 7).

Similar to the reports published by The Seattle Times, Walla Wall Union-Bulletin and The News Tribune went a step further to argue that some Mexican families forbade their children to speak Spanish at home (The News Tribune, 2007, p. 10; Walla Wall Union-Bulletin, 2008, p. 12). In this sense, the success of Hispanic immigrants was measured by their success of gaining membership from the dominant cultural group, which often came at the cost of losing their own 
cultural legacy and linguistic traditions. In addition, the absence of in-depth dialogue between the immigrants and their children who grew up thinking they were Americans might perpetuate the marginalization of immigrants in the host society for the following reason; the lack of knowledge on their parents' struggling experience as immigrants may turn some of these Mexican immigrants' children into tomorrow's anti-immigrant politicians (Ruiz \& Chavez, 2008, p. 167).

Furthermore, the term Mexican immigrants were unanimously replaced by Hispanic and Latino immigrants throughout these news reports. In particular, when describing the next generation of Mexican immigrants, the term Latino was mostly used to replace Mexican (The News Tribune, 2007, p. 10-11; The Seattle Times, 2011, p. 9-10; Walla Wall Union-Bulletin, 2008, p. 12-13). The newspapers reinforced the internal class stratification in Hispanic community through pulling Mexican immigrants out of the positive implication of cultural assimilation. Mexican-ness, if critically viewed according to the assimilationist rhetoric, was constructed as the impediment to Latino immigrants' successful assimilation into the host society. This discursive exclusion of Mexican immigrants from the process of positive socio-cultural integration upholds the dominant construction of Mexican immigrants as the illegal and marginalized socio-racial deviants.

\section{Discussion}

Moving away from traditional critical approach to media representation of the other, current project strived to illuminate a new path in theorizing how media forums operated under differing geopolitical agendas construct the images and life experiences of those struggling along the lines of social and national margins. The road that Mexican immigrants treaded through witnessed the turbulent history of immigrants who had to constantly negotiate their political status, cultural identities, and racial positions over differing historical stages (Ono \& Sloop, 2002; Ruiz \& Chavez, 2008).

Rather than returning to the epistemological assumptions and methodological strategies embraced by the preceding ethnographic studies and research on media representation, this study shifted its lens towards an usually taken-for-granted area of scholarly inquiry; how did a localized form of media discourse manifest itself in representing those physically included within the border of nation-state, whereas culturally excluded from the mundane imagination of national identity? Bearing this question in mind, I found that the newspapers published in WA re-produced the objectification of racial other through a commodification of Mexican immigrants as they are cheap laborers and a discursive denial of their entry into the spheres bounded by the ideal of cultural citizenship. In other words, the newspapers' marginalization of Mexican immigrants was achieved and naturalized through a dialectical way of positioning them as insiders who can contribute to the state's economy, and meanwhile, outsiders rejected by the host society. Moreover, my analysis unveiled the dominant construction of class stratifications and conflicting lived experiences internal to the Hispanic communities.

My analysis also showed that some news articles offered detailed accounts of anecdotes told by the Mexican immigrants. These narratives were rarely heard or examined in national news media. The recurring themes such as the Pursuit of American Dream and the Desire for Cultural Assimilation revealed what was usually absent across newspapers labeled as national, authoritative, and official. Further, different from national newspapers' rigid construction of Mexican immigrants as the absolute other rejected by the dominant cultural group, local newspapers used rhetorical construction of cross-racial friendship and the myth of American dream to perpetuate the hegemonic imagination of America as a country open to all immigrants. It is through this imagination the racist ideology supported by the practice of capitalism was erased and even justified to criticize the immigrants who failed to make that American dream true as lazy and incapable.

Of particular significance to my analysis is the strategic suturing of assimilationist discourse. For example, the newspaper articles implied that reaching one's American dream is in essence a process of becoming American. Working hard is important, but it would not guarantee you will make that dream come true. It is like the way the new Latino immigrants celebrated their loss of cultural heritage and interviewed Mexican immigrants' wholehearted gratefulness towards their American bosses' years of support to their families and careers. These narratives demonstrated that the pre-condition of realizing your American dream was to become what was defined as a true American by ethnic identity, use of language, and socio-cultural practices. These conditions insofar marginalized those who worked hard, yet refused to be assimilated or did not have the power, access, or ability to win the cultural membership. And even those who assimilated might not be considered as a full American. Nuanced traces such as accent, physical images, and the limitation of career choices as immigrants of color also placed them in a liminal space where they were forever in a process of becoming. In this sense, my critical analysis illuminated a new path in understanding how the newspapers' construction of otherness could be supported, normalized, and even glorified through positioning the assimilated other as superior to the absolute other. In a broader view, the newspapers used the construction of multiple others to naturalize the superiority of the dominant cultural values, practices, and perceptions. 


\section{Conclusion}

Drawing on the theoretical framework of media representation of immigrants, current study critically examined how newspapers published in WA represented Mexican immigrants. Four recurring themes emerged. These four themes revealed that the newspapers echoed the rhetoric of American dream through offering a series of highly selective and dramatic accounts of successful Mexican immigrants' self-reported life and work experiences. These news narratives represented American society as a free and accepting land that makes whoever willing to work hard happy and successful. In the meantime, the news stories attributed some immigrants' failures in achieving financial success and cultural assimilation to their personal laziness and stupidity. By placing the blames on individuals, the news articles shielded the larger cultural and legal system from being interrogated.

This strategic employment of individuals' experiences to reinforce culture-specific values evidenced Hall's (1997) hermeneutic approach to articulation as a form of de-contextualizing and re-contextualizing one's positions to support the dominant cultural norms. On a Macro-view, the overwhelming lack of media scrutiny on Mexican immigrants who entered U.S. legally and achieved success through higher education demonstrated another important aspect central to the dominant news discourse: it served the nationalist discourse denying the immigrants' legitimate access to other visible and respectable realms of professions and ways of achieving success (Don \& Lee, 2014; Esses, Medianu \& Lawson, 2013; Ono \& Sloop, 2002).

Confined to the spaces that are assigned by the dominant socio-cultural system, such as restaurants, farmlands, or implied lower position in Hispanic communities, Mexican immigrants' so-called successful assimilation was glorified only relative to those failing to make a fortune. This articulation of Mexican Immigrants' version of assimilation at some points rendered the oppressive aspects of cultural assimilation invisible and thus impossible to think of for other immigrants. Therefore, it is important to examine media representation of diverse immigrant groups. A study like this can help future scholars to re-think media representation from a more dynamic and multi-dimensional standpoint. Another limitation in the present study is the selection of newspapers as the data. Future research can analyze how other forms of media representation construct immigrants, either in relation to a variety of other immigrant groups or across different geopolitical locations. Hopefully in the near future, a new understanding of and approach to media representation of immigrants can be fostered.

\section{References}

Aguirre, J. A., \& Simmers, J. K. (2011). The dream act and neoliberal practice: Retrofitting Hispanic immigrant youth in U.S. society. Social Justice, 38(3), 3-16.

Brattston, D. W. T. (2014). Migrants, then and now. Compass, 48(2), 33-36.

Calvert, P. (2002). Relations with the United States. In P. Heenan \& M. Lamontagne (Ed.), The South American handbook. Chicago, IL: Fitzroy Dearborn Publishers.

Don, Z. M., \& Lee, C. (2014). Representing immigrants as illegals, threats and victims in Malaysia: Elite voices in the media. Discourse \& Society, 25(6), 687-705. http://dx.doi.org/10.1177/0957926514536837

Downing, J. D. H., \& Husband, C. (1995). Media flows, ethnicity, racism and xenophobia. The Electronic Journal of Communication, $5,2 \& 3$.

Dunaway, J., Goidel, R. K., Kirzinger, A., \& Wilkinson, B. C. (2011). Rebuilding or intruding? Media coverage and public opinion on Latino immigration in post-Katrina Louisiana. Social Science Quarterly (Wiley-Blackwell), 92(4), 917-937. http://dx.doi.org/10.1111/j.1540-6237.2011.00797.x

Esses, V. M., Medianu, S., \& Lawson, A. S. (2013). Uncertainty, threat, and the role of the media in promoting the dehumanization of immigrants and refugees. Journal of Social Issues, 69(3), 518-536.

Faiclough, N., \& Wodak, R. (1997). Critical discourse analysis. In T. Van Dijk (Ed.), Discourse studies: A multidisciplinary introduction (pp. 258-284). London: Sage.

Fairclough, N. (2009). Language and Globalization. Semiotica, 173, 317-342. http://dx.doi.org/10.1515/semi.2009.014

Hall, S. (1997). Representation: Cultural representations and signifying practices (Edited by Stuart Hall). London: Sage. http://dx.doi.org/10.1111/josi.12027

Lopez, A. (1991). Are all Latins from Manhattan? Hollywood, ethnography, and cultural colonialism. In L.D. Friedman (Ed.), Unspeakable images: ethnicity and American cinema. Urbana, IL: University of Illinois Press (pp. 404-424).

Miller, J. J. (1994). Immigration, the press, and the new racism. Media Studies Journal, 8, 19-28.

Ono, K. A., \& Sloop, J. M. (2002). Shifting borders: Rhetoric, immigration, and California's Proposition 187. 
Philadelphia: Temple University Press.

Richardson, J. (2007). Analyzing newspapers: An approach from critical discourse analysis. New York: Palgrave Macmillan.

Ruiz, M. V. (2002). Border narratives, HIV/AIDS, and Latina/o health in the United States: A cultural analysis. Feminist Media Studies, 2(1), 37-62. http://dx.doi.org/10.1080/14680770220122864

Ruiz, V. L., \& Chavez, J. R. (2008). Memories and migrations: Mapping boricua and chicana histories. Urbana and Chicago: University of Illinois Press.

Sanchez, C. A. (2014). 'Illegal' immigrants: Law, fantasy, and guts. Philosophy in the Contemporary World, 21(1), 99-109. http://dx.doi.org/10.5840/pcw20142119

Schemer, C. (2012). The influence of news media on stereotypic attitudes toward immigrants in a political campaign. Journal of Communication, 62(5), 739-757. http://dx.doi.org/10.1111/j.1460-2466.2012.01672.x

Scruggs, O. M. (1960). The first Mexican farm program. Journal of the Southwest, 2 (4), 319-326.

Stewart, C. O., Pitts, M. J., \& Osborne, H. (2011). Mediated intergroup conflict: The discursive construction of "illegal immigrants" in a regional U.S. newspaper. Journal of Language and Social Psychology, 30(1), 8-27. http://dx.doi.org/10.1177/0261927X10387099

Van Dijk, T. A. (1988). Semantics of a press panic: The Tamil 'invasion.' European Journal of Communication, 3, 167-187. http://dx.doi.org/10.1177/0267323188003002004

Vargas, J. Z. (2009). Latina teens, migration, and popular culture. New York, NY: Peter Lang Publishing.

Watson, B. R., \& Riffe, D. (2013). Perceived threat, immigration policy support, and media coverage: Hostile media and presumed influence. International Journal of Public Opinion Research, 25(4), 459-479. http://dx.doi.org/10.1093/ijpor/eds032

Zepeda-Millan, C. (2014). Perception of threat, demographic diversity, and the framing of illegality: Explaining (non) participation in New York's 2006 immigrant protests. Public Research Quarterly, 67(4), 880-888. http://dx.doi.org/10.1177/1065912914536470 